Contacts

Publisher: Ben Crowe

Editor: Paul Smaglik

Marketing Manager: David Bowen

European Head Office,

London

The Macmillan Building

4 Crinan Street

London N1 9XW, UK

Tel +44 (0) 2078434961

Fax +44 (0) 2078434996

e-mail: naturejobs@nature.com

Naturejobs Sales Director

Nevin Bayoumi (4978)

UK/ RoW/ Ireland:

Matt Powell (4953)

Andy Douglas (4975)

Frank Phelan (4944)

Scandinavia/ Spain/ Portugal

Evelina Rubio Håkansson (4973)

Natureevents: Sille Opstrup (4994)

France/ Switzerland:

Amelie Pequignot (4974)

Production Manager: Billie Franklin

To send materials use London

address above.

$\mathrm{Tel}+44$ (0) 2078434814

Fax +44 (0) 2078434996

e-mail: naturejobs@nature.com

Naturejobs web development

Tom Hancock

Naturejobs online production:

Ben Lund

European Satellite Office

Germany/ Austria/ Netherlands/

Italy/Belgium:

Patrick Phelan, Odo Wulffen

Tel + $498954905711 /-2$

Fax +498954905720

e-mail: p.phelan@nature.com o.wulfen@nature.com

US Head Office, New York

345 Park Avenue South,

10th Floor, New York, NY 10010-1707

Tel +1 8009897718

Fax +18009897103

e-mail: naturejobs@natureny.com

US Sales Manager: Peter Bless

US Advertising Coordinator

Linda Adam

Japan Head Office, Tokyo

MG Ichigaya Building (5F),

19-1 Haraikatamachi,

Shinjuku-ku,

Tokyo $162-0841$

Tel +81332678751

Fax +81332678746

Asia-Pacific Sales Director

Rinoko Asami

e-mail: rasami@naturejpn.com

\title{
naturejobs
}

\section{Shifting the balance}

$\mathrm{N}$ o one would argue that scientific jobs are dispersed unequally around the world. Western, developed countries, especially the United States and Britain, have a disproportionately larger share of funds, both in the public and private sector. As a result, they can attract scientists from parts of the world that have fewer resources or opportunities. There are long- and short-term views of the ramifications of this brain drain from poorer nations - and short- and long-term ways to deal with it.

The older, short-term view is that this is a crisis that requires outside intervention - perhaps investment of vast sums of money by monolithic entities such as the World Bank to allow the nations to build up their scientific infrastructure. A new view, explored in a collection of articles at SciDev.net, an online resource for science in developing countries, says that the brain drain is really 'brain circulation', and that a combination of market forces, good will and sound policy in the poorer nations can create scientific jobs there.

Market forces have already led Indian information-technology experts back from Silicon Valley to Bangalore. Good will especially when bolstered by philanthropic organizations such as the Bill and Melinda Gates Foundation — is leading Western science to pursue clinical research of AIDS and other infectious diseases in developing countries (see Nature 426, 736-737; 2003). And sound policy - in the form of repatriation grants, and a peer-review system free of corruption - is already being used in European countries that have lost scientists to the United States, and could easily be adopted by poorer nations.

It's likely that well-intentioned bodies will try both short- and long-term approaches. But the scientists will flow, as always, to where they have the most opportunities and fewest barriers to entry.

\section{Paul Smaglik}

Naturejobs editor

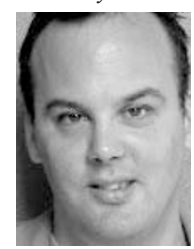

\section{Contents}

\section{CAREERS AND RECRUITMENT}

Geography's brave

new world

\section{CAREER VIEW}

\section{Scientists \& Societies}

Eurodoc

Graduate Journal

A tough challenge

Movers

Otmar Wiestler

WWW.NATUREJOBS.COM

Career centre

Information on the scientific job market
FOCUS

SPOTLIGHT

RECRUITMENT

ANNOUNCEMENTS

EVENTS 